\title{
The Theatrics of Protest: Bessie Harrison Lee and Performing the Values of the Woman's Christian Temperance Union
}

\author{
Jenny Caligari
}

Deakin University

\section{Abstract}

Australian women's activist, Bessie Harrison Lee (1860-1950) used her body and dress in performative, dynamic and innovative ways. Lee established herself as an integral part of a movement of women who exhibited exceptional stamina for public protest. At the beginning of Lee's career, she joined the Woman's Christian Temperance Union (WCTU) because it matched her ideals of how society could best nurture Christian values in the home and wider community. Many women who spoke in public spaces were educated and considered upper class, whilst Lee's early life was characterised by humble beginnings and lack of formal education. Despite the odds, she rose to prominence as President of the WCTU Footscray branch, Colonial Evangelist and Superintendent of Literature. Temperance or abstaining from alcoholic beverages was a primary goal that the WCTU and Lee promoted over a lifetime in multiple contexts in various continents. I argue that revisiting Lee's life shows us that the WCTU provided the environment for working-class women to move up through the ranks and publicly communicate radical ideas behind the veil of a hyper-conservative organisation. Women in this period, rather than shrinking from attention, utilised it to convey powerful messages for social change. 
Lilith: A Feminist History Journal, Number 26

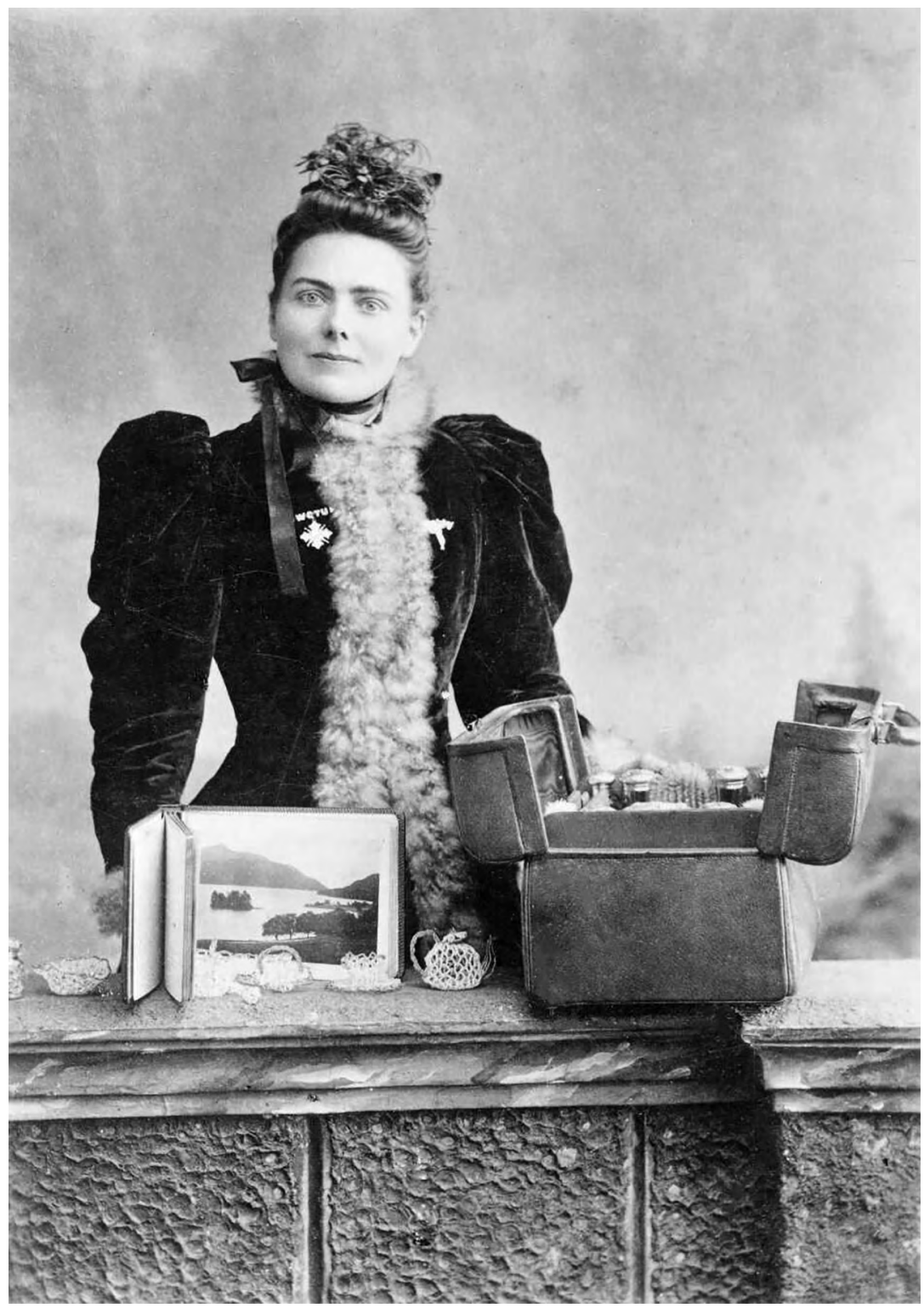

Figure 1: Lee behind a writing desk showcasing gifts from her travels.

Source: Mrs Harrison Lee, Marriage, Heredity and the Social Evil (London: H.J. Osborn, National Temperance Union Depot, 1903). 
Bessie Harrison Lee, a nineteenth-century Australian social activist, placed her image, a robust female body, as a central, exemplary focal point for Christian followers. This occurred from her beginnings as a Sunday School teacher where she would place herself in the middle of a small group of 'bootless, ragged children trundling hoops and playing imaginary cricket'. 'With the combination of her storytelling ability and aptitude for reading her audience, she was honoured in the Australian and British press with such commentary as having 'a clear, penetrating voice, deliberate utterance, kindly humour [which] allowed her to hold an immense audience in eager attention'. ${ }^{2}$ Her appearance, expressed in various media (photography, written publications and speeches), was indicative of her complex ideas about social issues that were marked by sustained activism over a lifetime in numerous forums and countries.

Lee was a significant leader of the late nineteenth-century women's movement in Victoria and internationally. She was born Betsy Vickery on 10 June 1860 in the mining town of Daylesford, Victoria. The town had undergone tremendous changes due to the discovery of gold in the decade prior to her birth. Amidst the backdrop of the profound historical changes to the townspeople of Daylesford, Lee and her siblings were separated after the tragic death of their mother in $1868 .{ }^{3}$ Lee was placed in the care of her aunt and uncle, who resided in the inner-city workingclass suburb of Footscray in Melbourne. During Lee's aunt and uncle's bouts of drunkenness, Lee was subjected to physical abuse. On hearing of Lee's treatment, her father Henry Vickery relocated her to the mining town of Enochs Point. Here she lived with another aunt and uncle who were firm in their deliverance of care, shown by Lee's recollection 'her aunt was unmerciful over any little peccadillo'. ${ }^{4}$ It was during this point that Lee experienced her religious 'conversion'. She believed that 'from that moment I was saved, thy sins are forgiven'. ${ }^{5}$ The mining environment of Enochs Point welcomed evangelical religious fervour as it provided dramatic relief from the dangers associated with mining. ${ }^{6}$ It also explained Lee's comfortable discussion of her personal religious experiences such as

\footnotetext{
1 Bessie Harrison Lee Cowie, One of Australia's Daughters: An Autobiography of Mrs Harrison Lee Cowie (London: James, 1924), 93.

2 'Mrs Harrison Lee', Queensland Times, Ipswich Herald and General Advertiser, 4 July 1903, 12.

3 Cowie, One of Australia's Daughters, 3.

4 Ibid., 30.

5 Ibid., 21.

6 Stuart Piggin, 'Two Spiritual Awakenings, Moonta Mines 1875 and Loddon River 1883', Evangelical Review of Theology, 31, no. 1 (2007): 65.
} 
conversion or 'glorious prayer'. ${ }^{7}$ Julie Melnyk highlighted that 'Evangelical theology', popular amongst mining communities, 'stressed the priesthood of the believer, that is the ability of the individual Christian to interpret God's revelation for himself or herself and to carry on a relationship with God without the intervention of clergy'. ${ }^{8}$ Robert Lee, a young miner, introduced Lee to his brother, a railway worker named Harrison Lee, and they were married at St Peters Anglican Church on 14 March $1880 .{ }^{9}$ Her career's beginnings lay in philanthropic work, specifically volunteering for the poor in refuges and gaols in the inner suburbs of Melbourne. This period of women's participation in charitable activities is reflective of Pamela Walker's observations that 'opportunities for laity, especially women emerged as they did not necessarily require ordination or a formal education'. ${ }^{10}$ When asking her husband whether she should join the Woman's Christian Temperance Union (WCTU), he replied: 'my dear, I think you had better accept the position'. ${ }^{11}$ With her husband's encouragement, Lee helped pioneer the WCTU in Victoria. ${ }^{12}$ The WCTU was an organisation that began in Ohio (USA) with the aim to promote moral character by education and example. ${ }^{13}$ Her public speaking career took Lee through remote rural Victoria, where she travelled by train, boat and horseback to promote a temperance lifestyle. Lee also helped establish the WCTU branch structure, which provided the resources for obtaining some 30,000 signatures for the Monster Petition of 1891 for female suffrage in the colony of Victoria. Besides relentless travel, speechgiving and pledge-taking, she wrote extensively for daily newspapers and the temperance press. In the middle phase of her career, Lee took on a highly visible role as an international campaigner for the World Women's Christian Temperance Union (WWCTU), one of only a few women to achieve this position. Not only did Lee travel abroad to countries such as Britain and the United States of America, she also toured less accessible

\footnotetext{
7 Cowie, One of Australia's Daughters, 38.

8 Julie Melnyk, 'Women, Writing and Theological Cultures', in Women, Gender and Religious Cultures in Britain, 1800-1940, eds. Sue Morgan and Jacqueline deVries (London: Routledge, 2010), 36, doi. org/10.1093/ehr/cer403.

9 Cowie, One of Australia's Danghters, 45.

10 Pamela Walker, 'Women, Preaching and Spiritual Authority', in Women, Gender and Religious Cultures in Britain, 1800-1940, eds. Sue Morgan and Jacqueline deVries (London: Routledge, 2010), 98, doi.org/10.1093/ehr/cer403.

11 Cowie, One of Australia's Daughters, 98.

12 Ibid., 98.

13 Jane Carey and Patricia Grimshaw, 'Woman's Christian Temperance Union of Australia', The Encyclopaedia of Women and Leadership in Twentieth Century Australia, www.womenaustralia. info/leaders/biogs/WLE0774b.htm.
} 
places. For example, Lee spent time visiting a Marae in New Zealand, spoke at leper colonies in Sri Lanka, and toured Natal and Zululand. ${ }^{14}$ Lee gave Australian women high visibility on the world stage when she spoke to a temperance audience at Exeter Hall, London, and completed voluntary work with Lady Henry Somerset at her Colony for inebriate women, Duxhurst. Lee's husband died on 17 January 1908. An admirer of Lee's work, Robert Cowie, a New Zealand farmer, wrote offering her marriage, and after much encouragement she accepted his proposal.

Lee's physical presence was larger than life, characterised by the delivery of her highly emotional, dramatic gestures and theatrics. During her final years in Pasadena, California, for example, she gained 'national wide fame when she staged a "Carry the Light" crusade into the bars and cocktail lounges of Pasadena'. ${ }^{15}$ Her weekly visits wearing placards around her neck were indicative of her public oratory. Her actions were the embodiment of a wider movement of women in the Judeo-Christian tradition who were engaged in discussions of the body in relation to heredity, eugenics, social evil (prostitution), marriage and voluntary motherhood. These women were navigating new pathways for women in the public sphere using their clothing and stance to communicate their arguments. Lee tirelessly utilised her physical body, through her demeanour and dress, in innovative and theatrical ways, and she did this consistently throughout her career as the manifestation of all that she believed in. Similarly, Elizabeth Nicholls, a contemporary of Lee's, became President of the South Australian WCTU. She too was described as a 'lucid speaker'. However, unlike Lee, she was from a privileged background and did not engage in the type of performativity that Lee did. ${ }^{16}$ Lee's unswerving placement of herself at the centre of her written and public appearances as a worker for the WCTU was central to her public persona. Lee presented herself as 'what you could be', or someone who could show 'the way'. In her own words, 'God has proved that a girl [herself] without education, money, influence, position or friends can by taking Christ's hand, and trusting her all to Him, rise to eminence'. ${ }^{17}$ By following Lee's example, a sanctified life could be obtained despite one's upbringing, whether it be in a working-class

14 Cowie, One of Australia's Daughters, 186.

15 '89 year old Temperance Crusader Dies in Sleep', Pasadena Star News, 18 April 1950, 2.

16 Marie Mune, 'Nicholls, Elizabeth Webb (1850-1943)', Australian Dictionary of Biography, National Centre of Biography, The Australian National University, adb.anu.edu.au/biography/ nicholls-elizabeth-webb-7839/text13613, 1988.

17 Cowie, One of Australia's Daughters, 153. 
environment or a family predisposed to alcoholism; she was proof that one could succeed. She therefore used herself as an example of someone who was self-educated, grew up around drinking and violence, and yet led a respected Christian lifestyle. Unlike other nineteenth-century preachers such as Catherine Booth or Jessie MacFarlane whose formative years were amongst the middle classes, Lee's childhood and early adulthood experiences were within working-class communities and her formal education was minimal. ${ }^{18}$

\section{Histories of Lee and the WCTU}

Valuable contributions have been made by scholars to restore Australian women's part in national and world suffrage history. ${ }^{19}$ Temperance was a major reform issue for most of the nineteenth century, an era that witnessed the development of successful women orators. Australian scholars have addressed the absence of temperance women in the history annals, building on Ian Tyrrell's extensive research, which employed an international lens to study women's public activism. ${ }^{20}$ Identifying temperance women more specifically in the Australian context, Lee is featured in a chapter by Patricia Grimshaw in the book Double Time: Women in Victoria, 150 Years, a collection of biographical studies that helped orientate Lee amongst prominent nineteenth- and twentiethcentury women. ${ }^{21}$ Grimshaw identified Lee's aunt as the one who instilled in Lee the importance of sexual purity in marriage, and she linked this to Lee's promotion of female personal autonomy. ${ }^{22}$ Lee further emerged as part of a new-world community of women who combined discussions of science with Christian ideals, as identified in Susan Magarey's work. ${ }^{23}$

18 Olive Anderson, 'Women Preachers in Mid-Victorian Britain: Some Reflexions on Feminism, Popular Religion and Social Change', The Historical Journal, 12, no. 3 (1969): 467-84, 470, doi. org/10.1017/s0018246x0000724x.

19 Denise George, Mary Lee: The Life and Times of a 'Turbulent Anarchist' and her Battle for Women's Rights (Adelaide: Wakefield Press, 2018), doi.org/10.1080/1031461x.2019.1662547; Myra Scott, How Australia Led the Way: Dora Meeson Coates and British Suffrage (Melbourne: Arcadia, Australian Scholarly Publishing).

20 Ian Tyrrell, Woman's World/Woman's Empire: The Woman's Christian Temperance Union in International Perspective, 1880-1930 (Chapel Hill and London: University of North Carolina Press, 1991), doi.org/10.1086/ahr/97.5.1608.

21 Patricia Grimshaw, 'The Politics of Purity', in Double Time: Women in Victoria, 150 Years, eds. Marilyn Lake and Farley Kelly (Ringwood: Penguin Books, 1995).

22 Patricia Grimshaw, Marilyn Lake, Ann McGrath, and Marian Quartly, Creating a Nation (Ringwood: McPhee Gribble Publishers, 1994), 187.

23 Susan Magarey, Passions of the First Wave Feminists (Sydney: UNSW Press, 2001), 3. 
This discourse on health, in particular women's control over reproduction, widened women's public role as experts on heredity and was a subject that featured in Lee's public debates and writings. ${ }^{24}$ Carol Mattingly, writing on temperance rhetoric, argued that 'labels such as conservative and radical inadequately described the complexity of women temperance leaders' arguments' ${ }^{25}$ Lee's public appearances in Church or public halls, evidenced vastly different delivery styles of dress and manner, from ostentatious to black Victorian dress. I suggest Lee walked a strategic line in promoting radical views to varied audiences, many hostile and even aggressive. Further, Mattingly's discussions surrounding the use of appearance to negotiate expectations and challenge and reconstruct the power hierarchy contribute to understanding the motivation and significance of Lee's many varied public appearances.

Australian women, including Lee, were at the forefront of debates surrounding women's suffrage. Clare Wright's You Daughters of Freedom tells the story of the victory of suffrage for women in Australia and therefore highlights the many public methods of protest utilised in Australia and overseas. ${ }^{26}$ In this work, Wright details a political world to which Lee was privy. There were other similar female political figures at the time who operated like Lee. For example, Wright's discussion of Vida Goldstein's public appearances alongside the likes of Alfred Deakin, Reverend Strong and the Lord Mayor illustrated how women representing various organisations were placed under scrutiny according to their dress and demeanour. Wright noted that the reports in the newspapers about Goldstein's speeches were loosely reported as 'her presence on the stage was newsworthy enough'. ${ }^{27}$ James Keating's work on Vida Goldstein identified her state, national and international loyalties. ${ }^{28}$ Lee similarly embodied this trend and declared herself 'One of Australia's Daughters', a title she was proud of during her national and international tours. Other literature that aided the analysis of Lee's public role is Yan Shu-Chuan's research on popular representation of fashionable female bodies in nineteenth-

\footnotetext{
24 Ibid.

25 Carol Mattingly, Well Tempered Women: Nineteenth Century Temperance Rhetoric (Carbondale: Southern Illinois University Press, 1998), 1; Carol Mattingly, Appropriating Dress: Women's Rhetorical Style in Nineteenth Century America (Carbondale and Edwardsville: Southern Illinois University Press, 2002). 26 Clare Wright, You Daughters of Freedom, The Australians Who Won the Vote and Inspired the World (Melbourne: Text Publishing Company, 2018), doi.org/10.1017/qre.2019.18.

27 Ibid., 36.

28 James Keating, “An Utter Absence of National Feeling”: Australian Women and the International Suffrage Movement, 1900-14', Australian Historical Studies, 47, no. 3 (2016): 462-81, 480, doi.org /10.1080/1031461x.2016.1194441.
} 
century periodicals. It acknowledges that the status of women and dress performed a major role in the social construction of identity, which assisted in decoding Lee's costumes and theatrical performances. ${ }^{29}$ Shu-Chuan argues that dress became a symbolic language, a kind of personal glossary and a species of body phrenology. Similarly, Lisa Tickner's work on the imagery of the British Suffrage Campaign 1907-14 contributed to historians viewing activists like Lee as part of the broad movement of women who utilised 'the agitation by symbol'. ${ }^{30}$ Taking from Tickner's argument, imagery that was cultivated in the public spectacle was 'not a footnote of or an illustration to the "real" political history going on elsewhere, but an integral part of the fabric of social conflict'. ${ }^{31}$

In this article, I contribute to the historical literature discussed here by focusing on the very theatrical and innovative nature of Lee's public performances, which were emblematic of public debates about social justice issues that were contemporaneous with Lee's performances. I argue that revisiting this aspect of Lee's life shows us that the WCTU provided the environment for a working-class woman to move up through the ranks and publicly communicate radical ideas behind the veil of a hyper-conservative organisation. Women in this period, rather than shrinking from attention, utilised it to convey powerful messages for social change. Historians like Olive Anderson show women preachers in Victorian Britain examined the 'drawing power' of early 'lady preachers' and the utilisation of dress to cultivate and demand a certain mood from the audience. ${ }^{32}$ Other case studies of female Christian followers such as Salvation Army worker Catherine Booth, or American Martha Neumark in the Judaism tradition, also confirm a rich history of women working the public arena using their posture, gestures or clothing to further their claims. ${ }^{33}$ Thus, historians have demonstrated the pivotal place of women

29 Shu-Chuan Yan, '(Ad)dressing Women: Fashion and Body Image in Punch, 1850s-1860s', Women's Studies, 43, no. 6 (2014): 750-73, doi.org/10.1080/00497878.2014.921510.

30 Lisa Tickner, The Spectacle of Women, Imagery of the Suffrage Campaign, 1907-14 (Chicago: University of Chicago Press, 1988), doi.org/10.1086/ahr/95.1.169.

31 Ibid., ix.

32 Olive Anderson, 'Women Preachers in Mid-Victorian Britain: Some Reflexions on Feminism, Popular Religion and Social Change', The Historical Journal, 12, no. 3 (1969): 467-84, doi. org/10.1017/s0018246x0000724x.

33 Roger J Green, 'Catharine Booth, The Salvation Army, and the Purity Crusade of 1885', Priscilla Papers, 22, no. 3 (2008): 9-18; Ellen M Umansky, 'Women in Judaism: From the Reform Movement to Contemporary Jewish Religious Feminism', in Women of Spirit: Female Leadership in the Jewish and Christian Traditions, eds. Rosemary Ruether and Eleanor McLaughlin (New York: Simon \& Schuster, 1979), doi.org/10.2307/3164818. 
and their embodied practices in such contexts. A study of Lee shows her as part of this movement, where women asserted their values in multiple contexts and adds to the above literature as a detailed examination of someone who, from working class not middle class, was similarly prominent and mobile. Lee sustained her public persona for the full duration of her career.

I begin this study by examining Lee's attendance in a coat of arms dress at the Colonial and Foreign Stall, London. She represented the newly created nation Australia in the celebration of the coronation of King George V. Then, I consider Lee's symbolic costume style during her passage on the ship Naldera to India. Furthering the study of Lee's performative dress style, I offer a discussion of her pageant presentations titled Bride of Many nations. I then turn to Lee's representation in photos and how they further enhanced her activism.

\section{Colonial and Foreign Stall}

The centrality and conspicuous public nature of Lee's appearances was exemplified by her arrival in a coat of arms dress to the Colonial and Foreign Stall, London, in 1911, which coincided with the Coronation of King George V of England at Westminster Abbey. Representations from British colonies attended, along with items that represented each colony's characteristics. 'Australian women', according to Keating, 'were enthusiastic member[s] of an International community' and Lee's presence in this event, culminating in the desire for Britain to enfranchise its women, evidenced this. ${ }^{34}$ This event took place after her marriage to her second husband Robert Cowie, her appointment as a WWCTU Missionary, and during the infancy of Australia's Federation. The wearing of the dress with Australia's coat of arms painted on its hem was significant because Lee used her body as a site to celebrate a new nation that was at the forefront of debates on contemporary social issues. At first glance, this ostentatious act appeared to contravene Evangelical values that emphasised spiritual inwardness; on the contrary, 'Evangelicalism gave women licence to move beyond home and hearth to places of diplomatic transnational forums' (London, in this case). ${ }^{35}$ Lee was reported in the Australian coat of arms 
costume in the numerous temperance and mainstream newspapers and in her own children's text, Auntie Faith's Rhymes. ${ }^{36}$ The South Australian women's temperance newspaper Our Federation wrote the following:

A public meeting in the evening was well attended, and proved of the highest interest. Mrs Stevens presided and ranged on the platform where the high officials of the union from many lands, Indian, Burmese, Australian, and Icelandic costumes were worn, adding a dash of colour that pleased the Genevese as much as the delegates themselves. Rev. M. Sauvin offered a prayer and afterwards kindly translated several speeches. Mrs Harrison Lee delivered a delightful speech. She was attired in a beautiful white satin dress, upon which was painted the Australian coat of arms and its motto 'Advance Australia' and a spray of the Australian wattle blossom crowned on her head. She excited great interest. ${ }^{37}$

Unapologetically bold at the stall, Lee signified the newly formed Commonwealth's authority and ownership; and rather than being quiet in movement and mind, she 'proved of the highest interest'. The infusion of colonial symbols provided an alternate iconography to the masculine images of colonial advancement - the bushman, shearer or pastoralist. As Chuan identified when studying earlier representations of women in magazines, the female body, adorned in this case with iconic wattle, could be used as 'a bearer of public sentiment, assumption and opinion within the context of fashion'. ${ }^{38}$ The celebrations of the new nation consisted of 'Britannia and her daughter Australia, a maiden in white', not dissimilar to what Lee was wearing on this occasion. ${ }^{39}$ The symbol of the new nation on public banners and press was a young, white, virginal Goddess and the entire spectacle of Lee's coat of arms dress was 'predicated upon an acceptance of the universality of whiteness', equated with purity, strength and morality. ${ }^{40}$ Events such as these illuminate the complex role women played in the formation of the values and ideals that the Federation was founded on.

36 Bessie Harrison Lee, Aunty Faith's Rhymes (Melbourne: JJ Howard, 1911).

37 'Advance Australia', Our Federation, 15 August 1903.

38 Yan, '(Ad)dressing Women', 753.

39 Raymond Evans, 'White Citizenship: Nationhood and Race at Federation', Memoirs of the Queensland Museum, Cultural Heritage Series 2, part 2 (2002): 182.

40 Ibid., 180. 


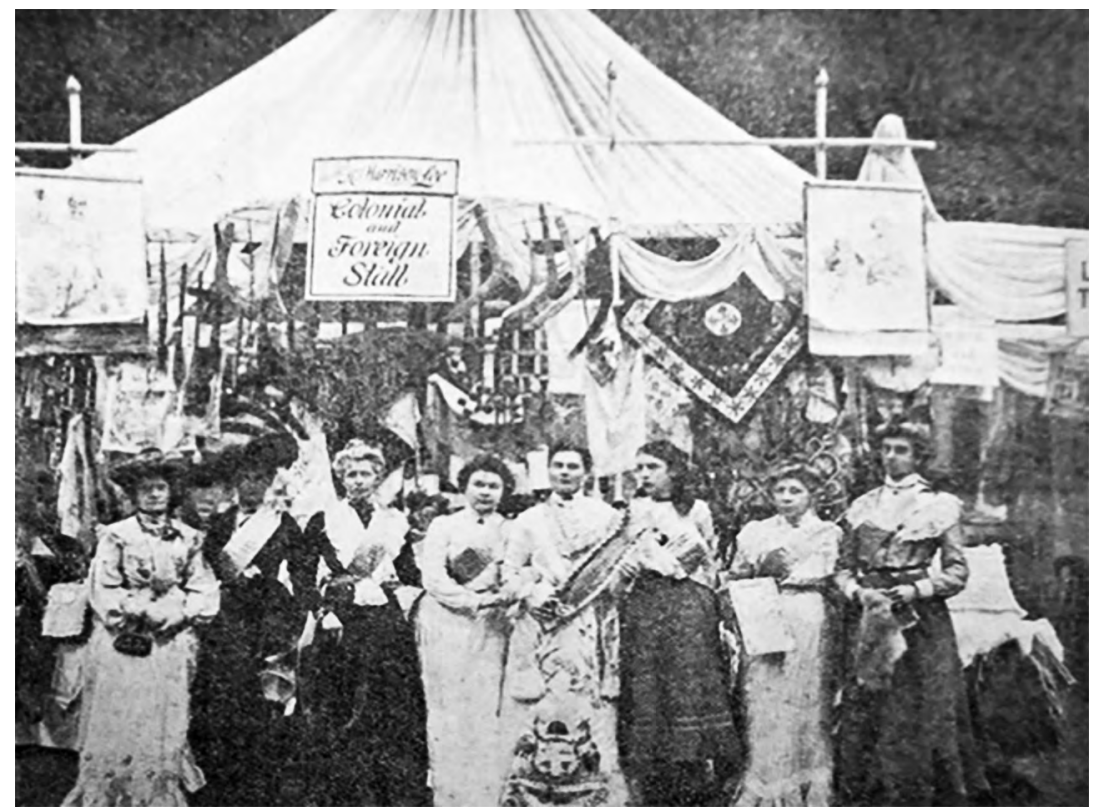

Figure 2: Auntie Faith's Bazaar Stall. Lee is fifth from left.

Source: Mrs Harrison Lee Cowie, Auntie Faith's Travels (London: Richard J James, Temperance Publishing House, 1910).

The idealisation of mother and home had been empowering for women and daughters; however, by the late nineteenth century, competing discourses of science, professional medicine and secularisation were eroding motherhood's authority. ${ }^{41}$ In centring herself, Lee and the WCTU worked against this trend and continued to elevate and affirm motherhood and articulate dissatisfaction with society's temptations. The public celebration of the newly formed nation framed within familiar metaphors of motherhood, purity and the home were also utilised in Lee's written autobiographies, where she would refer to the 'Goddess of Temperance versus Giant Alcohol'.42 These images encouraged questions about what it meant to be a woman in the early formative years of the nation. White women were elevated by their responsibilities to populate the new nation, where they 'had a central part to play in economic growth-

41 Patricia Grimshaw, Jim Hammerton and Eileen J Yeo, 'Introduction', Women's History Review, 8, no. 2 (1999): 193-9.

42 Bessie Harrison Lee Cowie, One of God's Lamplighters: Incidents in My Life-work. Being a Continuation of 'One of Australia's Daughters' (London: Ideal Publishing Union, 1902); Sue Morgan, 'Faith, Sex and Purity: The Religio-feminist Theory of Ellice Hopkins', Women's History Review, 9, no. 1 (2000): 18, doi.org/10.1080/09612020000200235. 
women in their capacity as mothers. ${ }^{43}$ White babies were a national asset, motherhood a national service. ${ }^{44}$ In early Federated Australia, as a result of these directives, white citizens received what were probably the most advanced welfare reforms in the world, the maternity allowance. ${ }^{45}$ While white married mothers received this bonus to boost the 'flagging birth rate against the threat of Asian invasion', these pronounced political rights, however, disadvantaged Aboriginal inhabitants. Evans argued: 'nowhere else on earth were Indigenous people so totally denied human rights by their conquerors. ${ }^{46}$

Lee's projection of herself with the coat of arms dress at the Colonial and Foreign Stall provided her room to show herself acting in different guises. She could cross traditional boundaries of female behaviour as modest and self-effacing to the forefront of flamboyancy.

\section{Naldera}

On board the passenger ship Naldera on voyage to India in 1924, Lee walked to a fancy dress ball exhibiting a similarly ostentatious style to the coat of arms dress, with large metaphorical pictures pinned to her skirt, chest and back communicating her temperance ideas. ${ }^{47}$ The purpose of Lee's journey was to visit 16 Christian missions in India and Ceylon, including leprosy colonies. ${ }^{48}$ When steam trains were first introduced in the early 1800 s, it was difficult for proper society to envision how a woman could travel in public and still adhere to the requirements of domesticity, as trains were projected as overwhelmingly masculine, brawny, dynamic and dominating. ${ }^{49}$ Lee presented herself as someone who was not reluctant to leave a domesticated space or her cabin

43 Grimshaw, Lake, McGrath and Quartly, Creating a Nation, 206.

44 Renata Howe and Shirlee Swain, 'Fertile Grounds for Divorce, Sexuality and Reproductive Imperatives', in Gender Relations in Australia, Domination and Negotiation, eds. Kay Saunders and Raymond Evans (Sydney: Harcourt Brace Jovanovich, 1992), 168, doi. org/10.1177/144078339603200308.

45 Evans, 'White Citizenship', 183.

46 Ibid., 184.

47 'Mrs Lee Cowie as "Prohibition”', White Ribbon, 18 June 1925, 7.

48 Cowie, One of Australia's Daughters.

49 Frances Steel, Oceania Under Steam: Sea Transport and the Cultures of Colonialism, c1870-1914 (Manchester: Manchester University Press, 2011); Frances Steel, 'Women, Men and the Southern Octopus: Shipboard Gender Relationships in the Age of Steam, 1870s-1910s', International Journal of Maritime History, 20, no. 2 (2008): 287, doi.org/10.1177/084387140802000214. 
(the ship equivalent), but relished being a spectacle, dominating the floor. The image of Lee as an eager participant in fancy dress represents a confident, strong woman who sat in tension with other conventional accounts of women as pious, pure, submissive and living within the domestic sphere. This is the description of Lee's 1924 voyage to India that was published in New Zealand's White Ribbon Journal. By then, she referred to herself as Mrs Cowie, or Mrs Bessie Lee Cowie, taking Robert Cowie's surname:

Mrs Cowie was dressed up as 'Prohibition', with big pictures on cloth, both on chest and back, and tied round her as a skirt; and she carried a banner which showed the sun in one corner, smiling down on the earth. The sun was prohibition, and on the earth was sitting a big frog called 'Booze', which said, "Soon there will not be a damp spot on earth." The pictures on her person were equally effective, representing a group of children to be saved, and a sieve showing all the different drinks that he manufactured from oats, barley, maize, etc., also a 'world' weeping, the result of drink, and a world smiling and happy when Prohibition comes. There were various mottoes, eg. "Sign the pledge and fight for abolition," etc. It was awfully good and she was a rare sport. She was very prominent, and it was a rare opportunity for Temperance propaganda. ${ }^{50}$

This description identifies Lee, nineteenth-century evangelical, temperance and suffrage activist, as a woman who maintained a consistently powerful public presence in both her oratory public performance and written publications. The melodramatic narrative of the story outlined on her dress had reached its conclusion, as good had overcome evil and moral order had been restored. Lee tapped into Victorian performance culture, the success of which depended not only on its fantastic spectacle, but also on the accessibility and popularity of its topical commentary. ${ }^{51}$ Women travellers were by no means celebrated and were often the focus of critical scrutiny; yet here Lee's dress demanded of her audience shock and thrill, through the comedic and the serious. ${ }^{52}$ Theatrical events orchestrated and acted by Lee saw their embryonic stages in performances like this, which showed the

50 'Mrs Lee Cowie as "Prohibition"', 7.

51 Peter Yeandle, Citizenship, Nation, Empire: The Politics of History in England, 1870-1930 (Manchester: Manchester United Press, 2015), 127, doi.org/10.1111/1468-229x.12179.

52 Indira Ghose, Women Travellers in Colonial India, The Power of the Female Gaze (Delhi: Oxford University Press, 1998), 8. 
importance of image creation to communicate and capture an imagined space of connectivity between WCTU women and the wider public. Lee's ostentatious performances continued throughout her career, drawing her more intimately to her audiences as opposed to ostracising her. On the contrary, up to a generation before Lee, many women who held careers in acting or other performance-related activities were not accepted as part of proper society. To illustrate this, Celeste Venard married Count Lionel de Chabrillan, the first French Consular Agent in the Colony of Victoria, much to his family's aversion. Celeste's highly scandalous memoirs included her participation in polka dancing, acting, riding horseback in a circus and her life as a Parisian courtesan. She was labelled the 'harlot spouse' by the early settler community. ${ }^{53}$ Similarly, Lola Montez, entrepreneurial actress and dancer, was reportedly conducting scandalous dance performances for the gold-digging community of Ballarat. ${ }^{54}$ The success of Lee's staged performances indicated cultural forces that were broadening the landscape for women's public activity. It also shows that Lee was confident to take risks and utilise forums such as a fancy-dress ball on the Naldera not previously available for women.

\section{Brides of Many Nations}

The success of Lee's staged performances indicated cultural forces that were not only broadening the landscape for women's public activity, but also using it as a vehicle to promote WCTU ideas on marriage and purity. The 'Brides of Nations Pageant', written and choreographed by Lee in Adelaide in 1908, intended to symbolise and unite women from different nations through the celebration of a wedding, an event that connected and engaged them with other women of the world.

53 Patricia Clancy and Jeanne Allen trans., The French Consul's Wife, Memoirs of Celeste de Chabrillan in Gold Rush Australia (Melbourne: Melbourne University Press, 1998).

54 Katina Banyai, ed., Bling, 19th Century Goldfields Jeweller (Ballarat: Museum of Modern Democracy, 2016), 53. 


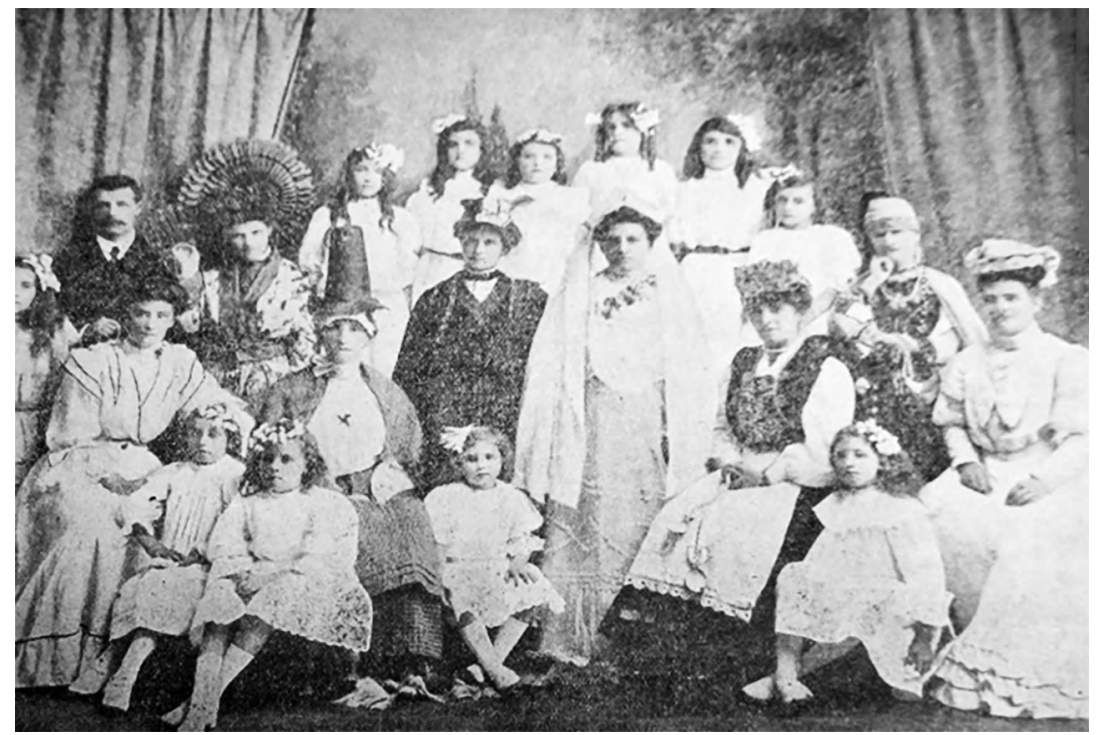

Figure 3: Brides of Many Nations.

Source: The White Ribbon, New Zealand, 15 October 1908.

This was not a linear narrative but a performance infused with familiar religious and cultural rituals that women of disparate British and European nations would have identified with. Women were universally the focal point of the marriage service, and so it was only natural that Lee used this in her performance to celebrate the Christian marriage and the success of prohibition in some countries, which elevated a bride's happiness. The Evening Post reported that Lee was:

Very theatrical in her addresses, she took her audience for a trip round the world, touching on many incidents and scenes she had witnessed during her travels. She referred at some length to what she had seen and heard of the Prohibition states in America. ${ }^{55}$

The glamour and lure of adventure unfolded majestically in front of her audience, her style derived from the pantomime traditions, the burlesque and the extravaganza. French, German, Scandinavian and Celtic folk stories were adapted for an English audience, and although told in a humorous tone, they often reverted to the serious message and complex

55 'Mrs Harrison Lee’s Mission', Colonist, vol. L, no. 1229 (1908): 2; 'No Licence', Evening Post, xxvi no. 22, 25 July 1908, 9. 
WCTU ideology of a Christian Temperance lifestyle. ${ }^{56}$ For example, Lee spoke and wrote about comical traditions behind Scottish courting rituals and then used the light-hearted tone of her talk to emphasise the Scottish 'war on whiskey'. ${ }^{57}$ Lee highlighted that 'the happiness of a bride was wrecked by "the evils of drink" and noted the Norwegian and Swedish brides were the happiest as their countries had many drink licences. ${ }^{58}$ What appeared as pantomime entertainment, however, subliminally offered a critique of indigenous races by their notable absence. When Indigenous Australians were included in the narrative it was done in a condemnatory, repetitive style, as exemplified by this quote in the Bendigo Advertiser:

Mrs Lee then gave an amazing description of the marriage customs of the Australian Aborigines. Usually when an Australian native wanted a bride he waited behind a gum tree and when a lubra appeared he simply struck her on the head with a club, and carried off his bride. That was the beginning and the end of the aborigines [sic] marriage festival..$^{59}$

As Philippa Levine noted, this is just one example of how writers borrowed freely from one another, superimposing imagery from enslaved and colonised women from diverse scenarios of racial difference. ${ }^{60}$ Through the reiteration of the above types of tropes, racial differences became entrenched in formal and informal conversation. For example, in her work on the early First Fleet accounts of bridal capture of Aboriginal women by their menfolk, Inga Clendinnen highlighted that 'too many reports were simply recirculation derived from a mere handful of speculative and unsubstantiated textual contrivances' ${ }^{61}$ Despite Lee's opportunities to access changing ideas, this was often not evident in her attitudes to race. The Bride of Many Nations cultivated a pictorial vocabulary of various ways of rejoicing in the Christian marriage, invited viewers to validate this, endorsed the reduction in liquor licences, and reminded the audience of the precarious position of the white race. Although Lee

56 Jennifer Schacker, 'Unruly Tales: Ideology, Anxiety and the Regulation of Genre', Journal of American Folklore, 120, no. 478 (2007): 381-400, doi.org/10.1353/jaf.2007.0066.

57 Bessie Harrison Lee Cowie, 'Brides of Many Nations', Goulbourn Evening Penny Post, 12 August $1913,2$.

58 Ibid.

59 'Temperance Crusade: Lecture by Mrs Harrison Lee "Brides of Many Nations", Bendigo Advertiser, 6 May 1908.

60 Philippa Levine, 'States of Undress: Nakedness and the Colonial Imagination', Victorian Studies, 50, no. 2 (2008): 189-219, doi.org/10.2979/vic.2008.50.2.189.

61 Liz Conor, Skin Deep, Settler Impressions of Aboriginal Women (Crawley: University of Western Australia Publishing, 2016), 93; Inga Clendinnen, Dancing with Strangers (Melbourne: Text Publishers, 2003), 159-60. 
emphasised the transnational experience of being a bride, she highlighted that 'the English wedding garb was the most charming of all', thereby reinforcing established racial thinking at the time. ${ }^{62}$ The opinion column of New Zealand's Ashburton Guardian reported:

Mrs Harrison Lee will address the Electors of Ashburton in the Oddfellows' Hall tonight, Thursday November 13 Mrs Harrison Lee's farewell meeting subject, "Beautiful Britain its blessings and its blight", as seen by a Colonial. The subject tonight will be "patriotic songs and beautiful views" illustrated on the canvas. ${ }^{63}$

In this public environment Lee was represented as an expert in her field, forging comparisons between celebration and criticism of British culture.

\section{New Zealand}

A photograph of Lee taken in 1899, during the first of many visits to New Zealand, shows her speaking authoritatively to a crowd on the evils of drink from the top balcony at Scotts Junction Hotel, Rangiora. ${ }^{64}$ It provides many clues to Lee's ability to craft a confident female space on this public stage. Her confidence is emphasised by her position overlooking and talking down to a male audience below. Her outer public representation in impeccable Victorian dress was socially coded to signify her exemplary moral character and emanated nothing but self-assurance. Lee stands where domestic staff traditionally stood to have their photographs taken, while their employers stood at the entrance below. These conventions conveyed 'contemporary knowledge of sexual difference and a rather obvious representation of women as domestic servants'. ${ }^{65}$ The image conformed to the separation of private and public spaces, of the spatial arrangements of pubs, and of sexual differentiation. Here the image subverts the traditional image of a male proselytising from a pulpit or political podium, his power emanating from the top balcony to the audience below. The framework encapsulates Lee's authorial role and how an Australian woman, energised by her relatively recent travels to Britain and Australia, was naturally confident to bestow her learned ideas to a hostile audience. The photograph captures the physical

62 Cowie, 'Brides of Many Nations', 2.

63 'No Licence Campaign', Ashburton Guardian, 13 November 1902, 3.

64 Alexander Turnbull Library F19635 1/2.

65 Diane Kirkby, Barmaids: A History of Women's Work in Pubs (Melbourne: Cambridge University Press, 1997), 59, doi.org/10.1086/shad18010100. 
manifestation of the rhetoric for which Lee was famous. At all the WCTU and WWCTU events, meetings and local option campaigns, when Lee delivered temperance speeches she placed herself at the centre of the physical stage and consistently privileged her narrative of life as a young vulnerable child in a volatile alcoholic environment as the prime motivator for her work. Lee's recollection of events, the feelings of loneliness, confusion, isolation, abandonment, dislocation from family and community qualified her to speak with experience. Lee's subsequent religious conversion, her intense inner spiritual life, provided the audience with keys to her identity and motivation. More importantly, it reaffirmed that heredity was not an excuse for 'wrong doing', as she used herself as an example: 'God has proved that a girl without education, money, influence, position, or friends can, by taking God's hand, and trusting her all to Him, rise to any eminence. ${ }^{66}$ Lee was exemplary in presenting herself as someone subjected to an alcoholic environment as a child, but who through faith and lifestyle rejected 'King Alcohol'.

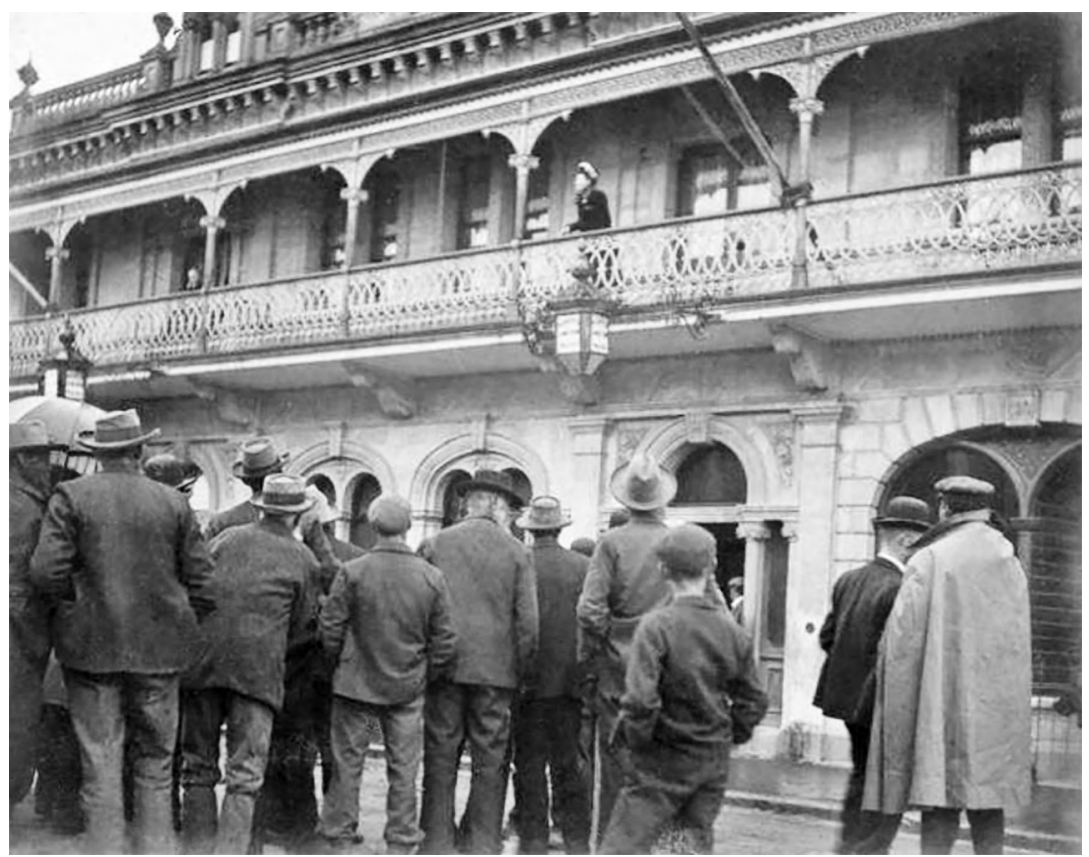

Figure 4: Lee on the top balcony of Scotts Junction Hotel, Rangiora.

Source: Mrs Harrison Lee, 'Scotts Junction Rangiora New Zealand', Alexander Turnbull Library, F196351/2.

66 Cowie, One of Australia's Daughters. 


\section{Holy Spirit Imagery}

The photographs that form an imperative part of Lee's publications utilise her image as an exemplary figure whose outward appearance signified, according to holiness teaching, the 'ever increasing likeness to Christ in love through the gracious indwelling presence of the Holy Spirit'. ${ }^{67}$ Within the framework of evangelicalism, the holiness movement identified that salvation transforms believers' inner lives in a way that actually helps them to live without committing sin. While different holiness churches have differing explanations on how this happens, they generally agree that the living Holy Spirit in believers helps them to obey God. ${ }^{68}$

The glorification of image was a trend evidenced in the WCTU, where portraits of Frances Willard, the leader of the American WCTU, were placed in a central position at their weekly meetings or official events. The image would replicate a religious environment, where flowers would adorn the border of Willard's portrait honouring her importance. Lee also adapted and refined this trend. She distributed photos of herself with captions on them to inspire temperance, reminiscent of the distribution of holy cards. In Yarragon, Victoria, Lee described a 'poor fellow' who requested her photograph. She recorded the exchange as follows:

A poor fellow just recovering from a drinking bout, came to the home at which I was stopping to get a pledge card, and to ask most humbly for the gift of inspiration to do better. I had in my work such a tremendous demand for photos, that in self-defence I had to put a price on them, and they were sold for the benefit of special branches of my far reaching enterprises. ${ }^{69}$

Whilst fashion potentially 'operated as a psychically powerful sign system for seducing women into becoming narcissistic, passive objects to be looked at by men', Lee transformed her image into a public display that sought to motivate the people she encountered. ${ }^{70}$

67 Charles Yrigoyen Jr and Susan E Warick, Historical Dictionary of Methodism (Lanham: Scarecrow Press, Inc., 2013), 186.

68 Kenneth J Collins, ed., A Wesley Bibliography, 5th ed. (Nashville, TN: First Fruits Press, 2016).

69 Cowie, One of God's Lamplighters, 24.

70 Yan, '(Ad)dressing Women', 762. 
Photographs were central to Lee's non-fiction publications Marriage and Heredity and Marriage, Heredity and the Social Evil. ${ }^{71}$ The studio photograph taken by Yeoman and Company (Melbourne) epitomises Lee as a site of empowerment, 'the bearer of Holyness'. ${ }^{72}$ It displays Lee behind a desk in a formal Victorian dress. The outfit is a typical 'tailor-made suit', the skirt slim in the front and still very full behind. The sleeves are long and her bodice short at the hip. Lee stands tall and wears a fur tippet, fashionable for middle-class women at the time-practical, comfortable and respectable. ${ }^{73}$

The encapsulation of the gender mores of Victorian society within Lee's photographic images operated by giving Lee latitude-giving her room to move without radically changing the normative rules governing gender difference. Accompanying her photograph are two biblical quotations: one from the Old Testament's Book of Isaiah (62:6), 'I have set watchmen upon thy walls, who shall never hold their peace day nor night. Ye that make mention of the Lord keep not silent'; and another from the New Testament's Gospel of Matthew, verse 8, 'Blessed are the pure in heart, for they shall see God'. These references are highly significant in elevating Lee's status as one of these 'watchmen' who 'shall never hold their peace'; hardly a command to be complacent, but to be a woman with a utopian vision that encompassed a female corrective that was urgently needed to establish an authentic Christian faith. Lee's photograph speaks of someone who was singled out to carry out God's work, a radical directive. The photos, poetry and biblical quotations position readers to observe Lee as someone who was endorsed to speak publicly about social concerns and provide direction forward. She wrote:

I am deeply impressed with the immensity of the task I have undertaken. Nothing short, indeed of attempting a revolution of all our social and domestic relationships; and as the work is great, so do I expect the reward to be great. ${ }^{74}$

Lee's confident style and inherent ideals displayed in the studio photographs were confidently reiterated in various mediums.

71 Bessie Harrison Lee Cowie, Marriage and Heredity (Melbourne: JJ Howard, 1893); Lee, Marriage, Heredity and the Social Evil.

72 'Colonial Evangelist's Report, 1889', WCTU Convention.

73 Yvette Mahe, 'Furs in Fashion in the Early Twentieth Century' (2013), www.fashionintime.org/ furs-fashion-early-twentieth-century/ (site discontinued).

74 Cowie, Marriage and Heredity. 


\section{Women and Travel: Lee's Journeys}

What was also extraordinary is the reporting of Lee's 11-month travels by The Woman's Signal, a weekly British temperance and women's magazine. Even in preparation of Lee's arrival, The Woman's Signal promoted her popularity with the following introduction: 'Among our colonial visitors this year, will be Mrs Bessie Harrison one of the best known and most successful of women Temperance advocates at the Antipodes. ${ }^{75}$ The editor Florence Fenwick Miller confirmed Bessie's popularity with:

Mrs Harrison Bessie our welcome Australian visitor has quickly received the best testimony possible to the pleasure that is given British women to receive a sister from out distant British Colonies she has already booked every date possible for addressing meetings during her stay in the Motherland. ${ }^{76}$

Over the 11-month travel period, Lee's photograph was published several times on the front page of The Woman's Signal and details of her interactions with fellow temperance workers documented. An example of one such article was a full-page commentary on Lee titled 'Mrs Bessie Harrison, A character sketch'. This article was accompanied by a large profile photograph of her centre page that endorsed her as a leading temperance figure. ${ }^{77}$ Whilst Miller thought that Lee could learn from British women's 'methods of welfare ... to demolish this giant foe', the editor was also open to what Lee 'could teach them'. ${ }^{78}$

75 Woman's Signal, 16 July 1896. The Woman's Signal was a weekly British feminist magazine published by Marshall \& Son, London, from 4 January 1894 to 23 March 1899. It was edited by Lady Henry Somerset, Annie Holdsworth and Florence Fenwick-Miller. Although primarily a temperance paper, it dealt with several feminist issues including fair wages. It began life as The Women's Penny Paper (27 October 1888 - 27 December 1890), edited by Helena B Temple (Henrietta Müller), later becoming The Woman's Herald (3 January 1891 - 28 December 1893). In 1892, Mrs Frank Morrison became editor, followed by Christina Bremner, then by Lady Henry Somerset in 1893. It was bought out by Lady Henry and renamed The Woman's Signal. Florence Fenwick-Miller bought the paper in 1895 and was the editor and sole proprietor until its demise in 1899 .

76 F Miller, 'Mrs Harrison Bessie, Our Welcomed Australian Visitor', Woman's Signal, 10 September 1896.

77 Woman's Signal, 30 August 1896, front page.

78 Miller, 'Character Sketch', Woman's Signal, 20 August 1896, front page. 
Twe Wounto Broxich, Acocor 20, 1800.

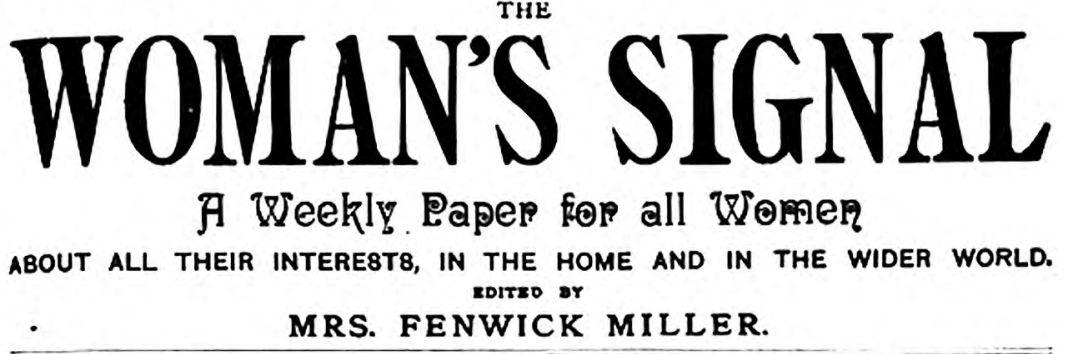

\begin{tabular}{|c|c|c|}
\hline Vor. VI., No. 138. & AUGUST 20, 1896. & On Ponny Woakly. \\
\hline
\end{tabular}

\section{Ebaracter Sketcb.}

MRS. HARRISON LEE.

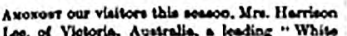

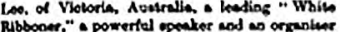

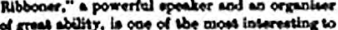
of ereas abasty. is coe of

Mm. Barrivos tee is known throaghost the

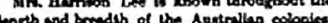
und by ber eotbuniastlo and ancereing leboars hes eamed for bereell the tisle of " Vistoris's Tecoperan os Gueve."

Tecoperan on thes.

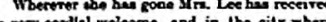
- rory cordlat webocke, and in lbe city were

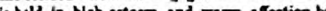

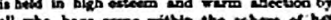
Introesce.

infracose.

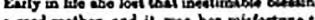
$\rightarrow$ cood molber, acd it wis her mialortase wo o lofl bo whe cart of an wank. Who thoagh good and hind reoggh ordinarily. Jet wae the herror

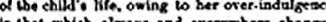
In thas wbich always and every bere change hamen boinge inss inhoman monskers-atroo

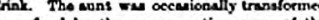
w - tend by the pecromentio power of the

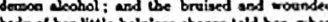
body ol bee till lo heipless charge lad ber, when withely relarsed, ol tbe depuld of enelly of

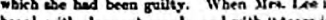
beard. with eloquent words. and with " heara in ber voike, pleseding for the listle cones whom tros are a desly martyriom becusen of tise the that we herielt bas

IIspplly, thin ebequered ebaplee of ber life

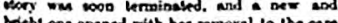
a chelser opened with ber rempinal bo the care

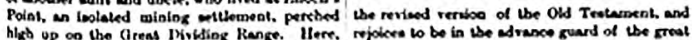

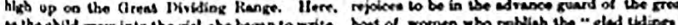

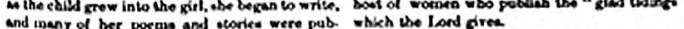
and inany of ber poecha and oconka were pus.

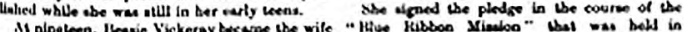

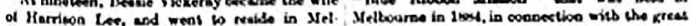
bourne. By degreses be was led into public erhibition ubere as that date. Wber laser. the

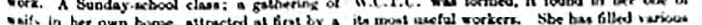
bets in ber own buaxe. attrached al hat zy a in ovile of pudding: a shibirea 3 metrike: the vis. the vepu wbich led eventually b ibe pulpit and

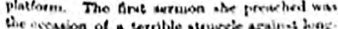
in most aueful rorkers. Sbe ban flled various.

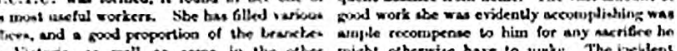

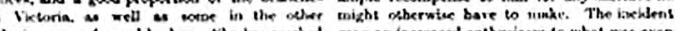

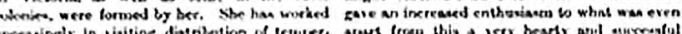

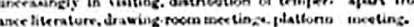

Figure 5: Lee featured on the front page of The Woman's Signal, A Weekly Paper for All Women About All Their Interests, in the Home and in the Wider World.

Source: The Woman's Signal, 20 August 1896. 
Not only was Lee traversing continents, but she was expanding her vision beyond the local and national boundaries of Australia and sharing aims for the betterment of humanity, while establishing her identity as a poised and dignified figure. This British publication described Bessie's achievements on her 11-month travels:

Wherever she has gone Mrs Bessie Harrison Lee has received a very cordial welcome, and in the city where she resided when not engaged in mission work, is held in high esteem and warm affection by all who have come within the sphere of her influence. ${ }^{79}$

Miller constructed Lee as exemplary and asked readers, 'Is Mrs Lee a New Woman? She is if the new woman is meant one who has a fuller development of the noble and lovable attributes of the old. ${ }^{\prime 80}$ This term was popularised at the time by Irish writer Sarah Grant, who promoted the image of a 'New Woman' in mind and action. Miller's choice of words encapsulated Lee as being independent, not just simply in her attitudes and values but in her engagement with a broader, more active world.

The inclusion of the following was also indicative of the characteristics Miller wanted to emphasise to a British woman's audience-a woman and marital arrangement they could emulate. Miller reported:

At a farewell meeting in Ballarat the most interesting features of the gathered was the maiden address of Mr Harrison Lee who though unaccustomed to public speaking in a few earnest words stated that his wife's work and labours had his thorough approval and he was only too glad to encourage her in her missions. Even though they involved frequent absence from home. The vast amount of good work she was evidently accomplishing was ample recompense to him for any sacrifice he might otherwise have to make. The incident gave an increased enthusiasm to what was even apart from this a very hearty and successful meeting. ${ }^{81}$

Miller used Harrison Lee's public support for his wife's travel and public profile as an exemplary model for her readers to emulate. Harrison Lee's endorsement of his wife's frequent absences from home is another reason why studying the life of Bessie is so enlightening on a number of levels. Her marital relationship, when juxtaposed with dominating

81 Miller, 'Character Sketch', Woman's Signal, 20 August 1896, front page. 
themes of masculinity promoted at the time in Australian journals such as The Bulletin highlights the varied social relations evident during this time. The magazine article invites us to look and contest the promotion of a type of masculinity that upheld male independence and considered domesticity abhorrent with the type of relationship Bessie and Harrison lived out both privately and publicly.

Other women equally placed themselves at the centre in the delivery of public addresses or public reports. For example, Victoria’s Vida Goldstein was noted for her wit and eloquence, and her ability to deal with hecklers. What is distinctive about Lee, however, is the longevity of her prolific writing and public speaking career and its particular ostentatious style. Many who were part of this generation of women who spoke in public became reclusive in the concluding years of their careers, or altered their method of attack. Vida Goldstein, for example, in her final years lived quietly with her sisters and pursued her role as a Christian Scientist practitioner.

Lee's enduring image personified the mental and physical stamina that sustained her career right up to her final years in Pasadena, California. While other women slowed down in their public duties, Lee failed to become despondent. Instead, she continued picketing bars by wearing placards, was featured on the cover of Life Magazine, and reported in numerous mainstream newspapers. In short, she was ambitious right up until her death in $1949 .{ }^{82}$ Her protests here were not dissimilar to her outlandish performance on the ship Naldera, or working the public speaking circuit in New Zealand. Lee gained nationwide fame in 1947 when she staged a 'Carry the Light' crusade into the bars and cocktail lounges of Pasadena, demanding the city enforce brighter lighting. After marching at the head of a band of 30 or 40 members of the WCTU, she succeeded in forcing the Pasadena Board of City Directors to pass a city ordinance requiring brighter illumination and improving the visibility of bars from the street. Her weekly invasions of the bars made national news and Life Magazine devoted several pages of pictures to her crusade in which she attempted to bring spiritual as well as physical light to the dark corners of Pasadena's bars.

82 'Cocktail Bars Raided by Bible Reading Women Who Meet Only Courtesy', Los Angeles Times, 26 April 1947, 1. 


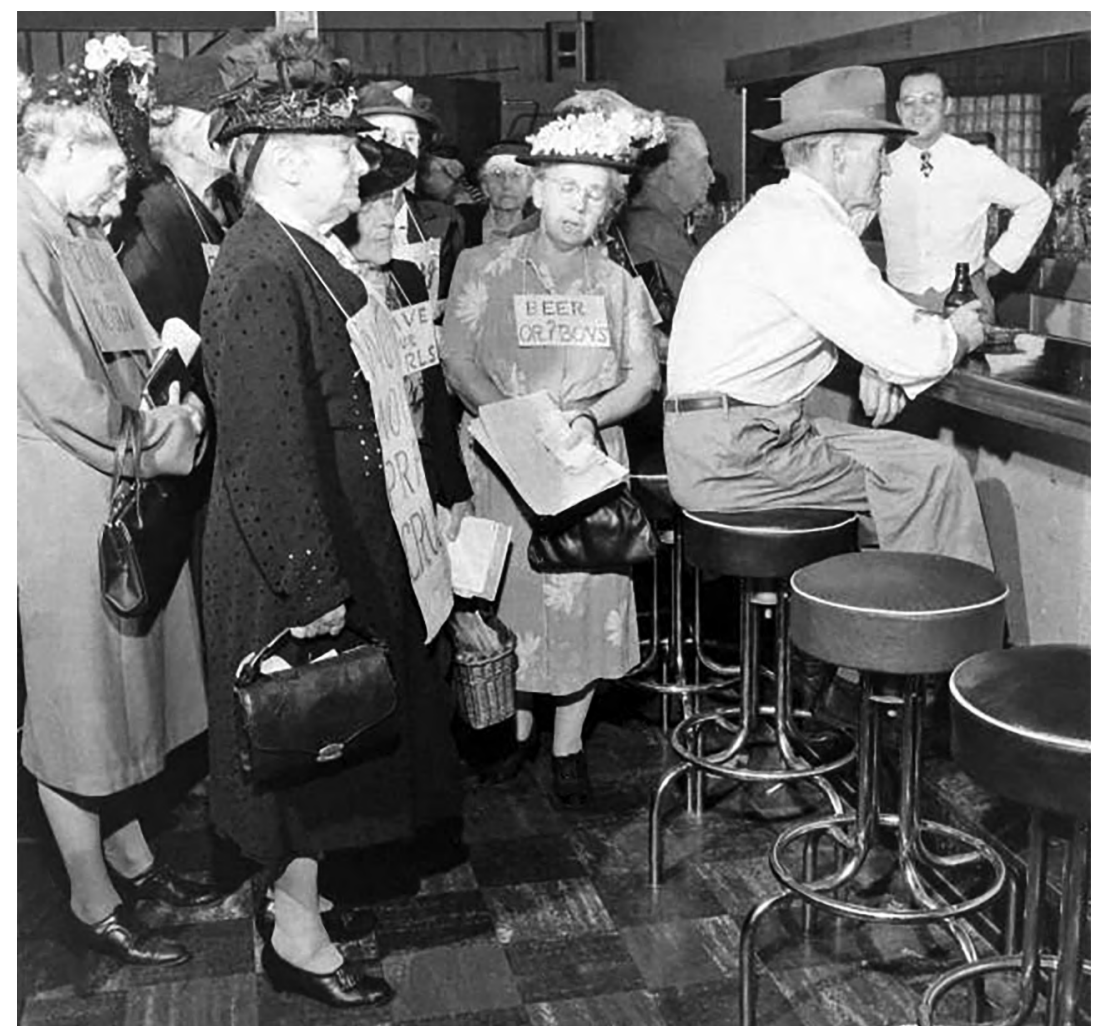

Figure 6: Lee protesting in Pasadena, California.

Source: Life Magazine, 19 May 1947.

\section{Conclusion}

Lee placed herself in the centre of public attention where she followed a long evangelical tradition of responding to introspective thought that manifested into action. Evangelicalism valued internal spirituality and the conversion experience, which involved an intense feeling of sins forgiven. From this belief, Lee wrote: 'The world has a right to all we possess, the right to the best that is in us.' The above evangelical ideas were embraced and Lee constructed her public appearances and autobiographies to walk a fine line between projecting herself as having a modest ego, while also promoting her sense of being sanctified. Despite her disadvantaged beginnings, her life was characterised by sustained public protest in the media and public oratory where she used her body to cultivate an atmosphere of Christian devotion and an aversion to alcohol. 
This text is taken from Lilith: A Feminist History Journal: Number 26, published 2020 by ANU Press, The Australian National University,

Canberra, Australia.

doi.org/10.22459/LFHJ.26.01 